\title{
Ruler Cult and Alexandrian Poetry. The Cases of Callimachus, Theocritus and Apollonius
}

\author{
Athanasios KOUTOUPAS \\ MA, Alexandrian Center for \\ Hellenistic Studies Egypt
}

Poetry was another «tool» by which the promotion of ruler's cult was able to become a reality. It is a fact that the larger part of the literature, belonging to the Hellenistic era, it was written in the courtyards of the palace and it was inextricably linked to the monarchy. Several texts with laudatory character addressed directly to the king make sure that this was one of the main themes of the poetry of the Hellenistic era. However the existence of poems with a more personal perspective, which do not appear to have a direct relationship with the king, reveal also their connection to the ruler.

The largest part of the laudatory poems is lost, since it was occasional poetry, which probably had never written down. However, there are several texts to provide the basic patterns of this kind, beginning with the image of the world as a kingdom. The laudatory texts included panegyrics, paeans, victorious odes and epics, ${ }^{1}$ while the same time epigrams also were an appropriate offer to the king and the members of his court, but also they were appropriate for the celebration on special occasions or the birth of a royal male who would be the future king. The paean of the king and the royal propaganda usually incorporated in other types of poetry. Theocritus for example wrote poems about the "royal gods" Heracles and Dionysus. ${ }^{2}$ In the work of Callimachus Aitia (Causes), Heracles appears as savior and civilized, who brought civilization to 


\section{Ruler Cult And Alexandrian Poetry}

barbarians. ${ }^{3}$ The description of Jason by Apollonius as primus inter pares of the Argonauts reflects the position of the first Ptolemies in relation to members of their Board. A more clear connection with the ideology of the king is the image of the Argonauts traveling to the edge of the world, leaving traces of sacred objects and rituals from where they passed, as well as stressing the important difference and tension between order and chaos. The work Aitia (Causes) includes stories about political and cultural expansion, and the promise of the Golden Age. ${ }^{4}$ Four laudatory poems of Theocritus withstood in time, while we have also pieces from other types. Callimachus and Theocritus wrote in the court of the Ptolemies in the reign of Ptolemy II Philadelphus and Ptolemy III Euergetes. ${ }^{5}$

Most of the poetry of the 3rd century BC which survives today was written in Alexandria in the period of the first three Ptolemies. The "Museum" and the Library, in conjunction with the welfare of the Ptolemaic kingdom, became an attraction for the spiritual world of the time, but also made the Ptolemies true heirs and protectors of the Greek culture. On one hand, the poets of the time praising the Ptolemaic kings as true successors of Alexander and through him as successors of Heracles also, while on the other, Alexandria is now the new Athens, cultural and commercial capital of the world. ${ }^{6}$

The "construction" of the Ptolemaic legitimacy in the 3rd century $\mathrm{BC}$ was notable both for the scale that was reached by the monarchs as well as for the complexity submitted to the poets. During the 3rd century there was no poetic background associated with the praising of the ruler who in one way or another was associated with a deity. These encomia were based on the recognition of an existing "commercial" relationship with the deity and the promise to continue this relationship with everything that this common course could mean. Thus this type of poetry, since it is based on an exchange model, always involves a negotiation about the identity and the authority. ${ }^{7}$ 


\section{Athanasios KOUTOUPAS}

From Zeus to Ptolemy I Soter and from Apollo to Ptolemy II Philadelphus

The comparison of Zeus (the principle of divine harmony) with the king (the principle of cosmic order), in philosophy, and especially in Stoics, is an element that appears also in poetry; for example, is an important element of the poetic cosmology of Aratus. The cult of Zeus Soter was dominant in Alexandria, while from 306 BC Ptolemy I acquired the nickname "Soter". Callimachus makes use of these two elements to describe a hidden relationship between Zeus and Ptolemy I Soter. ${ }^{8}$ This relationship is developed in the second and third verses of the first hymn (to Zeus), where the description of the power and the exploits of Zeus attributed equally to Ptolemy I Soter. ${ }^{9}$ Through the image of Zeus, the reader is directed to envision Ptolemy I Soter as a powerful king, who has to show a significant military success and who is the ultimate administrator of justice within his kingdom. ${ }^{10}$

Theocritus in his Idyll 17 praises Ptolemy, using the Homeric language, for virtues that are the same Homeric - such as martial valor, generosity, wealth, birth from a deity - and with which the kings of Homer are connected. No room is left, by the poet, through the presentation of features, to be denied any connection of Ptolemy II Philadelphus and the Homeric kings. The praising of Ptolemy I Soter, father of Philadelphus, who is connected with the divine element, not only through family ties with Heracles, but also through Alexander the Great, is one element. The relationship of Alexander the Great, God now, with Ptolemy presented in a manner reminiscent of the image of Zeus sitting on Olympus. ${ }^{11}$

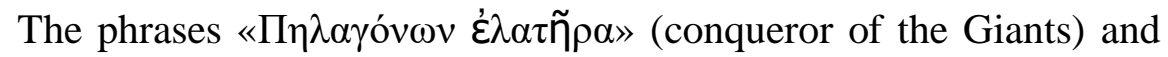

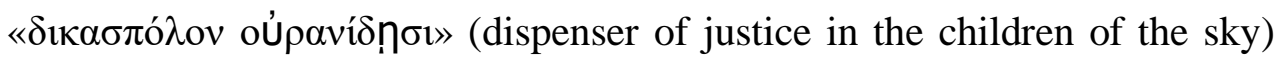
remind the Theogony of Hesiod. ${ }^{12}$ These references to Theogony show that Callimachus leads his readers to think about the establishment of a new divine order, but had ultimately aim to parallel between this image of Zeus with Ptolemy I Soter since he is installing a new political authority in Egypt. $^{13}$ 


\section{Ruler Cult And Alexandrian Poetry}

The figure of Apollo then in the human level corresponds to Ptolemy II Philadelphus. This was originally founded in verses 28-29 of the second hymn of Callimachus (in Apollo). ${ }^{14}$ Apollo is not an empty-handed son of Zeus. He has power and authority. The proof of this is the position held on the right of his father, Zeus. Thus Callimachus presents a divine union, father Zeus and Apollo son, which is above all. No one can question the absolute authority of Zeus, since this is the same God we see in the first hymn (in Zeus) to delegate tasks to other gods and he is this who is the dominant force in Olympus. Among the gods to whom Zeus allocating tasks is also his son Apollo. However the power of Apollo should not be underestimated. Instead it must be respected, since it is only less of the authority of Zeus. ${ }^{15}$

The image of Apollo sitting at the right of Zeus is not accidental incident. It is an obvious attempt of Callimachus to link the closeness of the divine relationship with the co-regency of Ptolemy I and II. So now we have the image of Philadelphus, young co-regent, sitting at the right of Ptolemy I Soter and to rule in Egypt, such as Zeus and Apollo rule the world.

This comparison is a key element of Idyll 17 of Theocritus, the encomium of Ptolemy II Philadelphus. This last poem focuses on the birth of Philadelphus and the deification of his parents, and it was written either on certain birthday anniversary, which is the most likely, or on the anniversary of the apotheosis of Ptolemy I Soter and Berenike I.

In the first verses of the poem Theocritus writes:

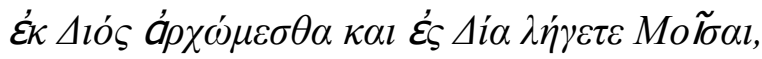

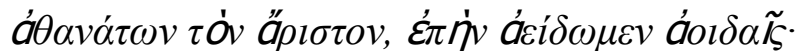

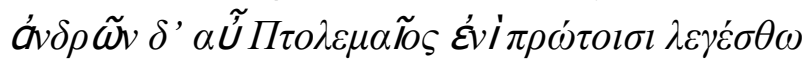

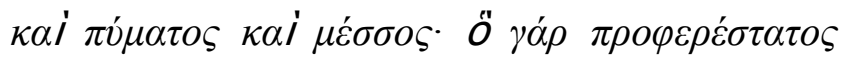
$a^{\prime} \delta \rho \tilde{\omega}{ }^{16}$ 


\section{Athanasios KOUTOUPAS}

(From Zeus let's start, Muses, and to Zeus let us finish each poem, because he is the first among the gods. But among mortals, Ptolemy is the first, first and last, and in between, since he is the best among people.)

Zeus is the king of heaven, while Ptolemy of the earth, thereby the macrocosm is linked to the microcosm. Later in the poem, Theocritus processes more this relationship. He says, therefore, that when Ptolemy II Philadelphus was born the heavens opened and an eagle appeared. And that was an omen, a sign sent by Zeus. Three times the eagle screamed over the crib of the newborn, making it clear that Ptolemy was the chosen one of Zeus. ${ }^{17}$ It is described also that Ptolemy I Soter has gained a place among the gods of Olympus after his apotheosis. ${ }^{18}$ Ptolemy I bequeathed to his son a rich and large kingdom, making the Ptolemaic dynasty the symbolic center of the world. ${ }^{19}$

This relationship between Olympus and the kingdom of the Ptolemies is distinct even through the marriage between Ptolemy II Philadelphus and Arsinoe II Philadelphus. ${ }^{20}$ At the same time it is maintained also a relationship with the Egyptian tradition. If the Egyptian example for wedding between siblings is Osiris and Isis, ${ }^{21}$ Zeus and Hera is the Greek equivalent. ${ }^{22}$ Although by some it is supported the opinion that the analogy between the marriage of the Ptolemies and that of Olympus is not clear, ${ }^{23}$ however the naturalness with which it follows the above link through this poem in conjunction with what is recorded by Plutarch in his work "Moral", ${ }^{24}$ about the marriage of Ptolemy II Philadelphus and Arsinoe II Philadelphus leaves hardly room for doubt.

\section{Peace and Prosperity}

Another issue which appears in the hymn to Zeus is the relationship of the king with the fertility of the earth. Callimachus locates the birth of Zeus not in Crete but, based on another legend, in Arcadia. Arcadia until 


\section{Ruler Cult And Alexandrian Poetry}

then was an inhospitable region, but since the birth of Zeus transformed into a fertile and productive region. ${ }^{25}$ In the encomium to Philadelphus also the images of fertility and good luck are abound. ${ }^{26}$

For the peace to come, first should be conducted the war. Chaos must be defeated in order to ensure order. A common theme in the royal ideology is to present the king as eliminator of barbarians. Thus, the barbarians who were threatening the order of the Hellenistic world were the Celts. Antigonus Gonatas used his victories over the Celts to legitimize his position as the king of Macedonia, while he and Attalus I got the adjective "Saviour" after their victory over the Gauls. 276 BC the Celts invaded Greece, but they were defeated at Delphi. The victory at Delphi was attributed to divine intervention of Apollo. This intervention of Apollo appears in the fourth hymn (in Delos) of Callimachus, but here Callimachus succeeds to give part of the triumph to Ptolemy II, although he did not participate in this battle. However succeeds connecting Philadelphus to the triumph when Apollo, in the womb of Leto yet, foretells conflict of Ptolemy II Philadelphus with the Celts. ${ }^{27}$

The story which Apollo foretells here is the suppression of the rebellion of the Celt mercenaries of Ptolemy II's army during the first Syrian War. The army of Ptolemy managed to isolate the rebels on an island in the Nile and there to kill them by setting fire to the crops of the island. ${ }^{28}$ Thus Callimachus managed to equalize Philadelphus with Apollo and the victory of the latter in Greece. Both were savior gods who saved the world from the barbarians. Simultaneously, Philadelphus manages to overcome his opponent Antigonus Gonatas, whose victory against the Celts in the battle of Lysimachia (277 BC) gave him prestige and the throne of Macedonia. In the hymn to Delos, only Apollo appears as a winner in Greece, while the name of Gonatas is silent.

Ptolemy II Philadelphus is praised with terms which were attributed to kings far behind in the Greek tradition, at a time before the emergence of the city-states of the old Greece, and long before the conquests of Alexander 


\section{Athanasios KOUTOUPAS}

the Great and the wars of his Successors. The ideology of monarchy is the same as that on which Alexander the Great created its own royal ideology: divine origin, martial prowess, and respect for the gods and generosity to men coming from his personal wealth. These are the features highlighted by the tradition of Alexander the Great in the presentation of its achievements and Theocritus does no more than to incorporate them in the personality of Ptolemy II Philadelphus. ${ }^{29}$

\section{The "Argonautica" of Apollonius}

The story of Jason and the Argonauts is just a compilation of myths and fiction and epic. Generally, Jason, a Greek hero, and his companions go to the easternmost edge of the known world, the land of Colchis, to recover the magical fleece. There they accept the help of the daughter of the king of the region, which Jason later marries and brings back to Greece. The story hides two basic patterns. The search for a precious object and the meeting of the Greek element with the barbarian, the other, and the resulting collaboration and final union of the two. This union can be viewed in different ways: as a mutual association of the Greek and the barbaric element, as a triumph of the Greek civilization over the barbaric, as vilification of the Greek innocence and values from the barbaric treachery and magic, as an indication of easy cultural connection. Placing the fact in the past all cases are possible. Similarly, there is no independent account of the events which Apollonius mentions except a series of previous myths and legends, each embedded in a specific context. ${ }^{30}$

Apollonius chose a story in which the meeting of the Greek world with the world of the barbarians is the key element, in contrast to the heroic battles or the homecoming. But Colchis is not just another form of the barbaric world. In the work Argonautica, referred to as Egyptian. Initially, Apollonius proposed a connection with Egypt by using one of the most characteristic narrative strategies of Herodotus. For Herodotus the reversal of the Greek cultural structures is central and characteristic behavior of the Egyptian, and in the Argonautica, as the Argonauts approaching Colchis, 


\section{Ruler Cult And Alexandrian Poetry}

experiencing a rapid escalation of such reversals. The Argonauts faced the Tivarinous who have a strange custom associated with pregnancy, the Mossynoikous who make in public whatever the rest are doing in private, and in the third book the local burial customs upset the natural order exposing the corpses in the air, instead of the burial. Thus Apollonius constructs a narrative continuity of more foreign peoples and behaviors, which climaxes as the Argonauts arrive in Colchis. There, they find king Aeetes, who is the son of the sun. The Egyptian pharaoh (and by extension the Ptolemies) was for the purposes of worship son of the Sun (Ra) ${ }^{31}$ Moreover in the 4th book, although Apollonius does not mention the name, makes it quite clear that Colchis was founded by Sezostris, the legendary Egyptian conqueror. ${ }^{32}$

Apollonius created for the Ptolemies a past in which Greece meets Egypt, recovers from it a valuable object (the fleece), which is already Greek, through the divinely inspired cooperation of Medea with the enemy, affect a return, within which, again through divine grace, one of the Argonauts is identified as the ancestor of those Greeks who were destined to inherit North Africa. ${ }^{33}$

\section{The Coma Berenikes}

Sometimes the poems which were written in the Ptolemaic court had two reading levels. The first was the one that had obvious influences from the Greek myths and the Greek thought and the second level was the one that was reflecting the Egyptian ideas filtered through the Greek tradition. One of these poems is the Coma Berenikes, belonging to Callimachus and preserved by Catulus. The Coma Berenikes is dated to $245 \mathrm{BC}$, when it is discovered the namesake constellation. This is essentially two years before Ptolemy III Euergetes includes himself and Berenike II in the Alexandrian cult of the Sibling Gods.

When Ptolemy III Euergetes started for the Third Syrian War, Berenike II promised to dedicate one coma from her hair to the temple of 


\section{Athanasios KOUTOUPAS}

Arsinoe in the bay of Zefiri in exchange for the safe return of the king. Berenike II keeps her promise, but the coma that she had offered disappeared the next day of the offer. The mathematician and astronomer Conon of Samos, then it finds the coma as a celestial constellation. ${ }^{34}$ Thus, in cooperation the discovery of the constellation of Conon and Callimachus' poem reflect perfectly the atmosphere that prevailed in the Ptolemaic court, which perhaps was the cause of the disappearance of the coma of the Queen. Since the hair of the queen can become constellation, then divine attributes should be recognized to the queen. This certainly is a way to demonstrate the atmosphere in the royal court, and also demonstrates the way in which continuously the divine character of the kingdom is propagated. ${ }^{35}$

Generally the poem Coma Berenikes develops a complex rhetorical strategy for the dissemination of a dynastic myth, which comes in addition to the already existing and the same time its purpose is to support the marriage of Ptolemy III Euergetes and Berenike II. Through the constellation resulting from the separation of the coma of the Queen, Callimachus was able to present the divine character acquired by the queen, and by extension the royal couple, through a romantic picture of passion that unites Ptolemy III and Berenike II. ${ }^{36}$

When Berenike II proceeds to deposit her coma in the temple of Arsinoe in Zefyrio she is not only inspired by the Greek tradition but she is influenced also by certain acts attributed to Isis according to Egyptian mythology. The story concerns a practice similar to that in which Berenike II proceeds, but the central figure now is Isis, who devotes to Koptos a lock from her hair during the mourning for her husband Osiris. ${ }^{37} \mathrm{It}$ is a fact that in Koptos it was demonstrated to the visitors a lock of hair as a relic of hair that had dedicated by Isis. For this reason Isis of Koptos considered during the Hellenistic period as a deity associated with hair. The lock of Isis symbolized resurrection and rebirth. ${ }^{38}$ 


\section{Ruler Cult And Alexandrian Poetry}

\section{Additional Poetical References}

Apart from the type of the immediate encomium as we have seen to be accomplished in the examples with which we dealt, the poets had found also indirect ways to present the similarity, or rather better to emphasize the match of the Ptolemaic kings with corresponding Greek heroes and deities, and especially with those who negotiate somehow the gap between man and god. ${ }^{39}$ Thus we see that in the 24th Idyll of Theocritus, entitled "Little Hercules", the poet attempts to present a clear cultural connection, which is become strongly understandable when we consider that the Ptolemies claimed descent from Heracles. But the poet himself is trying to lead the reader to this conclusion emphasizing more strongly one, otherwise, veiled reference to the date of birth of Ptolemy II Philadelphus, which seems to coincide with that of the ancestor of the hero, now deified. Similarly in the 18th Idyll (hymeneal for Helen), which presents a song about the marriage of Helen and Menelaus, and which seem to serve as a mythical model for a Ptolemaic wedding like the one between Ptolemy II Philadelphus and Arsinoe II Philadelphus, since it implies the possibility that the queen, as the daughter of Zeus, Helen, has the seeds of a deity. It is relevant also the Hymn to the Dioskouroi (Idyll 22), in which it is emphasized that Castor and Pollux, the brothers of Helen, located in a system which is shared between mortal and immortal nature, and their worship was of particular interest for Arsinoe II Philadelphus, which during her marriage to Lysimachus of Thrace, tried to tie herself to the worship of the sacred place of Samothrace, and maybe that's why she proceeded with the introduction of their worship in Alexandria. ${ }^{40}$ This highly significant relationship between Dioscuri and Arsinoe II is evident in the work of Callimachus "Apotheosis of Arsinoe", in which it is mentioned, that the Dioskouroi carry the body of the dead queen in her new heavenly home. ${ }^{41}$ 


\section{Athanasios KOUTOUPAS}

\section{Epilogue}

These works (of Callimachus, Theocritus and Apollonius) which are written within the limits of the royal court of the Ptolemies were aimed directly to praise the king and the members of the Ptolemaic dynasty adapting elements from the Greek poetry of the classical era, taking always into consideration the needs that arise in most monarchs of the Hellenistic era, who have claimed and finally acquired a form of divine nature and status.

The content of these poems was in its bigger part connected with the classical era of the Greek city-states, because the audience in which they addressed is the Greek citizens of Alexandria, since the purpose of the first Ptolemies was to promote the idea of their deification in them. For the Greeks the idea of a deified live ruler was not a usual practice, ${ }^{42}$ while this idea exists in the Egyptian tradition with the pharaoh as son of Ra.

Finally, we should mention that in order to understand completely the phenomenon of the deification of the ruler we should combine also other means of "propaganda", such as coins, inscriptions, statuary and temples. In this paper we focused on the literary evidence, providing the necessary "tools" for a future more extended research on the topic. 


\section{Ruler Cult And Alexandrian Poetry}

Notes:

1 About the technical differences between the various forms of praise poetry -

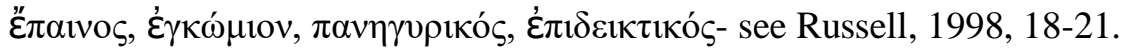

2 Idyll 24 and 26.

3 Harder 2005, 246.

4 Ibid.

5 The works of these two poets, although written within the boundaries of the palace courtyard, however their content influenced by the Egyptian environment of Hellenistic Alexandria, see Stephens 2003.

6 Hunter 2005, 483.

7 Depew 2004, 117-118.

8 Hussey 1993, 24-25.

9 Callimachus Hymn 1.2-3.

10 Hussey 1973, 25.

11 Samuel 1993, 181.

12 Callimachus Hymn 1.3, while the respective sections in the work of Hesiod are 881-885.

13 Hussey 1993, 26.

14 Callimachus Hymn 2.28-29.

15 Hussey 1993, 63-64.

16 Theocritus Idyll 17.1-4.

17 Theocritus Idyll 17.71-76; Hazzard, 2000, 92.

18 Theocritus Idyll 17.16-25; Hunter, 2003, 78.

19 Theocritus Idyll 17.91-96.

20 Theocritus Idyll 17.129-134; Hunter 2003, 88-90; 190-194. On marriage between Ptolemy II Philadelphus and Arsinoe II Philadelphus and how this practice continued by the next Ptolemies, see also Hazzard 2000, 82-100.

21 Koenen 1993, 61-62. It should also be added here the fact of the pharaonic tradition that numberscases of marriage among siblings, which probably plays the role of motivation to the Ptolemies to follow this practice, showing continuity and connection with the Egyptian Pharaoh, Ager 2005, 17.

22 Chauveau 2000, 31; Lloyd 2002, 403.

23 Hazzard 2000, 89-93.

$2473.6 f$.

25 Callimachus Hymn 1.18-35.

26 Theocritus Idyll 17.77-83.

27 Callimachus Hymn 4.171-190. 


\section{Athanasios KOUTOUPAS}

28 Pausanias 1.7.2.

29 Samuel 1993, 181.

30 Stephens 2000, 197.

31 The worship of Egyptian gods continued during the reign of the Ptolemies, who with every possible media of propaganda tried to make known that they are the natural continuation of the Pharaohs, that they are pious rulers and thus they have the support of the gods, Noegel 2004, 133.

32 Stephens 2000, 198-199; Noegel 2004, 126.

33 Stephens 2000, 203.

34 Callimachus Coma Berenikes frg. 110. Concerning this information see also Catulus 66.

35 Koenen 1993, 90.

36 Gutzwiller 2007, 191.

37 Plutarch Isis and Osiris 14.

38 Hölbl 2001, 105.

39 Gutzwiller 2007, 190.

40 Fraser 1972, 207; Depew 2004, 130.

41 Gutzwiller 2007, 191.

42 There are many examples of Greek kings who attempted to promote their deification, but without success. Upon these examples the Hellenistic ruler based their attempts. The Spartan commander Lysander is worshipped on Samos, the Macedonian king Amyntas III in Pydna, while Philip II of Macedonia in Amphipolis. FGrH 76F.26 кaı 71. 


\section{Ruler Cult And Alexandrian Poetry}

\section{BIBLIOGRAPHY}

Ager, S.L. 2005. Familiarity Breeds. Incest and the Ptolemaic Dynasty. Journal of Hellenic Studies 25: 1-34.

Chauveau, M. 2000. Egypt in the Age of Cleopatra (transl. D. Lorton). New York.

Depew, M.2004. Gender, Power and Poetics in Callimachus' Book of Hymns, in A.M. Harder (ed.), Callimachus II (Hellenistic Groningana). Leuven: 117-137.

Frazer, P.M.1972. Ptolemaic Alexandria. Vols. I-III. Oxford.

Gutzwiller, K.2007. A Guide to Hellenistic Literature. Oxford.

Harder, A.2005. Rondom de ivoren toren: Hellenistische poëzie als l'art pour l'art?. Lampas 38.3: 239-248.

Hazzard, R.A. 2000. Imagination of a Monarchy. Studies in Ptolemaic Propaganda. Toronto.

Hesiod, 2007. Theogony. Works and Days (transl. G.W. Most), Loeb Classical Library. Cambridge.

Hölbl, G. 2001 A History of the Ptolemaic Empire ( $\mu \varepsilon \tau \alpha \dot{\varphi} \varphi \rho$. T. Saavedra). London-New York, 2001.

Hunter, R. 2003. Theocritus, Encomium of Ptolemy Philadephos. Berkeley.

Hussey, W.D. 1973. Politics and Poetry in the First Two Hymns of Callimachus. Columbus.

Jackson, S. 2001. Callimachus: Coma Berenices: Origins. Mnemosyne 54:

1-9.

Koenen, C. 1993. The Ptolemaic King as a Religious Figure, in A. Bulloch (ed.), Images and Ideologies. Self-definition in the Hellenistic World. Berkeley: 25-114.

Lloyd, A.B. 2002. Ptolemaic Period, in I. Shaw (ed.), The Oxford History of Ancient Egypt. Oxford: 395-421

Noegel, S. 2004. Apollonius' Argonautika and Egyptian Solar Mythology. The Classical World 97: 123-136. 


\section{Athanasios KOUTOUPAS}

Pausanias, 1918. Description of Greece. Vol.1 (transl. W.H.S. Jones), Loeb Classical Library. Cambridge.

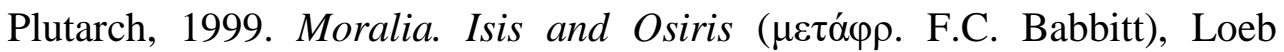
Classical Library. Cambridge.

Russell, D. 1998. The panegyrists and their teachers, in M. Whitby (ed.), The Propaganda of Power. The Role of Panegyric in Late Antiquity. Leiden, Boston, Cologne: 17-49.

Samuel, A.E. 1993. The Ptolemies and the Ideology of Kingship, in P. Green (ed.), Hellenistic History and Culture. Berkeley: 168-210.

Stephens, S.A. 2000. Writing Epic for the Ptolemaic Court, in M.A. Harder - R.F. Regtuit (eds.), Apollonius Rhodius. Leuven.

Stephens, S.A. 2003. Intercultural Poetics in Ptolemaic Alexandria. Berkeley. 